\title{
Effectiveness of photoelectrocatalysis treatment for the inactivation of Candida parapsilosis sensu stricto in planktonic cultures and biofilms
}

\author{
Regina H. Pires $^{\mathrm{a}, *, 1}$, Michelle F. Brugnera ${ }^{\mathrm{b}, \mathrm{c}, 1}$, Maria Valnice B. Zanoni ${ }^{\mathrm{b}}$, \\ Maria José S.M. Giannini ${ }^{\mathrm{a}, *}$ \\ a Department of Clinical Analysis, Clinical Mycology Laboratory, UNESP-Universidade Estadual Paulista, Faculdade de Ciências Farmacêuticas, Araraquara, \\ SP, Brazil \\ ${ }^{\mathrm{b}}$ Department of Analytical Chemistry, Institute of Chemistry, UNESP-Universidade Estadual Paulista, Araraquara, SP, Brazil \\ ${ }^{\mathrm{c}}$ Department of Chemistry, UFMT-Universidade Federal de Mato Grosso, Cuiabá, MT, Brazil
}

\section{A R T I C L E I N F O}

\section{Article history:}

Received 2 February 2015

Received in revised form

18 November 2015

Accepted 19 November 2015

Available online 22 November 2015

\section{Keywords:}

Photoelectrocatalysis

C. parapsilosis

$\mathrm{Ti} / \mathrm{TO}_{2}$ nanotubes electrodes

Biofilm

\begin{abstract}
A B S T R A C T
Photoelectrocatalysis (PEC) has become an attractive technology to disinfect microorganisms from aqueous environments because of its ability to degrade microorganisms without producing any harmful by-products. PEC methodology was applied to inactivate Candida parapsilosis sensu stricto in planktonic and biofilm cells, and its efficiency was compared to that of photolytic and photocatalytic treatment. In the case of planktonic (free-floating) cells, PEC promoted the inactivation of $10^{6} \mathrm{CFU} \mathrm{mL}^{-1}$ after $3 \mathrm{~min}^{-}$ of treatment, and the addition of silver nanoparticles to the $\mathrm{Ti} / \mathrm{TiO}_{2}$ electrodes had virtually no effect on the disinfection period, although it caused a decrease by a factor of 1.5 in the mineralization efficiency. After 60, 10 and 60 min of treatment, PEC methodology reduced $10^{6} \mathrm{CFU} \mathrm{mL}^{-1}$ on fungal biofilms and provided 71, 91 and 92\% mineralization for biofilm cells performed on polyvinyl chloride (PVC), silicone, and polytetrafluoroethylene (PTFE), respectively. These results indicated that PEC is a promising process for disinfection of water contaminated with $C$. parapsilosis sensu stricto in both planktonic and biofilm cells.
\end{abstract}

(C) 2015 Published by Elsevier B.V.

\section{Introduction}

Conventional methods used to disinfect microorganisms include chlorine, chlorine dioxide, ozone, and ultraviolet radiation. Among these methods, the chlorination process can lead to the formation of toxic by-products, such as carcinogenic trihalomethanes [1]. Thus, for this purpose, new technologies have been developed by highlighting the application of heterogeneous photocatalysis, focusing primarily on the use of $\mathrm{TiO}_{2}$, which has shown excellent properties [2-6]. When $\mathrm{TiO}_{2}$ is excited by UV irradiation $(<400 \mathrm{~nm})$, electron-hole pairs are generated on the semiconductor. In the presence of water and oxygen, hydroxyl radicals $\left(\bullet^{\bullet} \mathrm{OH}\right)$ are formed [7], which are potent and nonselective oxidizing agents. This effect could be used for the degradation of organic matter [8,9] and disinfection process [10]. This method can promote the mineralization

\footnotetext{
* Corresponding authors at: UNESP-Universidade Estadual Paulista "Júlio de Mesquita Filho" Rodovia Araraquara-Jaú, Km 1, 14801-902 Araraquara, SP, Brazil. E-mail addresses: rehepi@gmail.com (R.H. Pires), giannini@fcfar.unesp.br (M.J.S.M. Giannini).

1 These authors contributed equally.
}

of organic matter, generating nontoxic such by-products as $\mathrm{CO}_{2}$, $\mathrm{H}_{2} \mathrm{O}$ and inorganic compounds.

Photocatalytic inactivation of bacteria and viruses has been reported [11-13]. Nevertheless, few reports have described fungi that are eukaryotic organisms. According to the morphology of its cells, these fungi can be divided into two major groups: yeast forms (single-celled fungus) and filamentous forms (multicellular fungi or mold). The fungi have a definite cell wall that contains polysaccharides, including glycans and chitin, and reproduce by means of spores [14]. Furthermore, fungal cells attach to surfaces to form biofilms, where cells are embedded in a matrix that constitutes a conglomerate of different types of biopolymers, such as extracellular polysaccharides (EPS), proteins, nucleic acids, lipids and other biopolymers, such as humic substances [15,16]. Moreover, the presence of a matrix provides a physical barrier to the diffusion of chemical disinfectants $[15,16]$.

Since the late 1970 s, fungal infections have increasingly become a significant cause of morbidity and mortality $[17,18]$. Candida albicans is the most common pathogen; however, Candida parapsilosis has become the leading causative agent in South America $[19,20]$. It has been reported that $C$. parapsilosis represents a 'complex' of genetically different strains/species and consists of at least three 
genetically separate species, Candida orthopsilosis, Candida metapsilosis and C. parapsilosis sensu stricto [21]. C. parapsilosis infections have often been associated with the use of indwelling catheters and its ability to produce biofilm on prosthetic materials [19]. In addition, $C$. parapsilosis species were found in haemodialysis water systems [22-24].

In view of the efficiency of $\mathrm{Ti}-\mathrm{TiO}_{2}$ nanotubes applied in photoelectrocatalytic methods for the disinfection of such microorganisms as bacteria and viruses [11-13,25], and in view of the absence of studies focused on the disinfection of $C$. parapsilosis, this paper evaluates its viability and effectiveness to remove yeasts from the aqueous phase completely, particularly C. parapsilosis sensu stricto in both biofilm and planktonic form.

\section{Experimental}

\subsection{Disinfection assays}

The photoreactor cell is a cylindrical Pyrex-glass cell with a $250 \mathrm{~mL}$ capacity equipped with water refrigeration using an ultrathermostatic bath. The reaction temperature was controlled at $20 \pm 1{ }^{\circ} \mathrm{C}$ with an ultra-thermostatic bath. The cell was filled with fungal solution or biofilms in $0.05 \mathrm{M} \mathrm{Na}_{2} \mathrm{SO}_{4}$ at $\mathrm{pH}$ 6, and a working electrode $\left(\mathrm{Ti} / \mathrm{TiO}_{2}\right.$ or $\left.\mathrm{Ti} / \mathrm{TiO}_{2}-\mathrm{Ag}\right)$, an auxiliary electrode (Pt gauze), and an $\mathrm{Ag} / \mathrm{AgCl}(3 \mathrm{M} \mathrm{KCl})$ reference electrode applied potential of $+1.5 \mathrm{~V}$ vs. $\mathrm{Ag} / \mathrm{AgCl}$ and $\mathrm{UV}$; all conditions were previously optimized by Brugnera et al. [10].

The $\mathrm{Ti} / \mathrm{TiO}_{2}$ nanotube electrodes were prepared by anodization of previously polished and cleaned titanium foil $(0.5 \mathrm{~mm}$ thick, $25 \mathrm{~cm}^{2}$ ) in a two-electrode cell configuration, where the Ti was the anode and platinum was the cathode. Anodization was performed at a constant voltage of $30 \mathrm{~V}$ for $50 \mathrm{~h}$ in a solution of $0.25 \mathrm{wt} \% \mathrm{NH}_{4} \mathrm{~F}$ with glycerol and water $(90: 10 \mathrm{v} / \mathrm{v})$. Finally, the photoelectrode was fired at $450^{\circ} \mathrm{C}$ for $30 \mathrm{~min}$ in a muffle oven (EDG 3P-S) [26]. The deposition of $\mathrm{Ag}$ nanoparticles on the self-organized $\mathrm{Ti} / \mathrm{TiO}_{2}$ nanotube electrodes was achieved by immersing in a solution $0.05 \mathrm{~mol} \mathrm{~L}^{-1}$ $\mathrm{AgNO}_{3}(\mathrm{pH} 8)$ and incubating the container for $12 \mathrm{~h}$ in conditions of dark and vacuum. Afterwards, the film was irradiated with UV light for $2 \mathrm{~h}$ to convert the $\mathrm{Ag}$ ions into Ag metal [27]. Finally, the photoelectrode was fired at $450{ }^{\circ} \mathrm{C}$ [10]. SEM images indicated that $\mathrm{TiO}_{2}$ nanotubes with a diameter of $150 \mathrm{~nm} \pm 10 \mathrm{~nm}$ grew uniformly over the entire Ti substrate; the $\mathrm{Ti} / \mathrm{TiO}_{2}-\mathrm{Ag}$ were covered with $\mathrm{Ag}^{0}$ nanoparticles with a diameter of $50 \mathrm{~nm}$, as described previously [10].

A $125 \mathrm{~W}$ Philips medium pressure mercury lamp $\left(I=9.23 \mathrm{~W} \mathrm{~m}^{2}\right.$, $\lambda=315-400 \mathrm{~nm}$ ) without the glass, inserted in a quartz bulb was immersed in the photoreactor cell. A potential of $1.5 \mathrm{~V}$ vs. $\mathrm{Ag} / \mathrm{AgCl}$ was achieved using an Autolab PGSTAT-300 potentiostat/galvanostat (Eco Chemie). Air bubbles were introduced into the microbial suspension using a pump to homogenize the solution. The experiments were performed in four distinct conditions: (i) photoelectrocatalytic treatment (PEC), using $\mathrm{Ti} / \mathrm{TiO}_{2}$ nanotube electrode + UV irradiation + bias potential $1.5 \mathrm{~V} \mathrm{vs.} \mathrm{Ag/AgCl;} \mathrm{(ii)} \mathrm{PEC-}$ $\mathrm{Ag}$ with $\mathrm{Ti} / \mathrm{TiO}_{2}-\mathrm{Ag}$ nanotube electrode $+\mathrm{UV}$ irradiation $+1.5 \mathrm{~V}$; (iii) photocatalytic (PC) treatment using UV irradiation and $\mathrm{Ti} / \mathrm{TiO}_{2}$ electrode, and (iv) photolytic (PO) treatment by using only UV irradiation. The microorganism was submitted to treatment for 3,5 , $10,30,60,120$ and $180 \mathrm{~min}$. Test specimens in the 0 -min condition were untreated and constitute the control or $100 \%$ survival organisms. Subsequently, the inactivation was monitored by the survival assays. Analytical-reagent-grade chemicals (Sigma-Aldrich Co.) were used and prepared with sterile distilled water. All glassware used was washed with distilled water and then autoclaved at $121^{\circ} \mathrm{C}$ for $15 \mathrm{~min}$. All experiments were carried out in triplicate on three different occasions.

\subsection{Organisms}

C. parapsilosis sensu stricto (WCP123) collection strain was used in this study. Previously, this strain was recovered from the hydraulic system of a haemodialysis center and maintained at $-80^{\circ} \mathrm{C}[22-24]$. The strain was identified by a PCR-based method with specific primers directed against the secondary alcohol dehydrogenase (SADH) gene [23] and screened for its ability to form biofilm $[22,28]$. Prior to experiments, the strain was propagated in yeast extract-peptone-dextrose (YPD) medium (1\% [ $\left.\mathrm{wt} \mathrm{vol}^{-1}\right]$ yeast extract, $2 \%\left[\mathrm{wt} \mathrm{vol}^{-1}\right]$ peptone, $2 \%\left[\mathrm{wt} \mathrm{vol}^{-1}\right]$ dextrose (Difco)) in an orbital shaker ( 75 r.p.m.) for $24 \mathrm{~h}$ at $37^{\circ} \mathrm{C}$. Cells were harvested and washed twice with $1.5 \mathrm{~mL}$ of water. Concentrations of Candida spp. were adjusted to $10^{6} \mathrm{CFU} \mathrm{mL}^{-1}$ (colony forming unit) in $0.05 \mathrm{M}$ sodium sulphate by haemocytometric counting.

\subsection{Biofilm formation}

Three different types of polymeric synthetic materials were used for biofilm formation: (i) polyvinyl chloride (PVC), (ii) silicone, and (iii) polytetrafluoroethylene (PTFE). The materials were cut in disks $13 \mathrm{~mm}$ in diameter and sterilized with UV irradiation for $20 \mathrm{~min}$. Fungal biofilms were prepared according to previously described protocols [29,30]. Candida was grown as described above. The resultant growth was harvested, washed twice in sterile distilled water and adjusted at a concentration of $10^{6}$ cells $\mathrm{mL}^{-1}$ in Roswell Park Memorial Institute (RPMI) 1640 medium supplemented with Lglutamine, buffered with morpholinepropanesulfonic acid (MOPS) and added to $0.9 \%$ of glucose. An aliquot $(1000 \mu \mathrm{L})$ of $10^{6}$ cells $\mathrm{mL}^{-1}$ was added to the wells of a 24-well microtiter plate (Corning Inc. Corning, NY, USA) onto appropriate discs. Biofilms grew at $37^{\circ} \mathrm{C}$ for $48 \mathrm{~h}$; then they were taken out and washed in water to remove non-adherent cells. Two discs with biofilms (quantity to obtain $10^{6}$ cells $\mathrm{mL}^{-1}$, defined by our previous experiments) were placed into the reactor and submitted to each disinfection technique. After each time point treatment, the sample was immediately removed from the reactor and sonicated for 2 min to uniformly disperse the cells from the disks.

\subsection{Survival assays}

Aliquots $(10 \mu \mathrm{L})$ of appropriate dilution (from $10^{-1}$ to $10^{-5}$ ) from both planktonic and biofilm samples were plated on Sabouraud agar plates and incubated at $30^{\circ} \mathrm{C}$ for $48 \mathrm{~h}$. All colonies were counted and expressed as Colony Forming Units (CFU) per $\mathrm{mL}$. The limit of detection for the viability assay was $10 \mathrm{CFU} \mathrm{\textrm {mL } ^ { - 1 }}$ $[13,31]$. The percentage of disinfection was determined by counting the number of CFUs of treated $C$. parapsilosis sensu stricto compared to the number of colonies obtained from untreated suspensions (time point $0 \mathrm{~min}$ ). All experiments were assessed in triplicate on three separate dates.

\subsection{Evaluation of C. parapsilosis sensu stricto degradation}

The yeast cell wall consists of organic compounds that include polysaccharides, lipids and mannoproteins [14]. Thus, the effect of photoelectrocatalysis on the degradation of organic compounds released from $C$. parapsilosis sensu stricto during treatment was monitored. The total organic carbon (TOC) dissolved from the destroyed microorganism was monitored using a total organic carbon analyser (Shimadzu TOC-V CPN).

In addition, a Shimadzu Model 10AVP high-performance liquid chromatography (HPLC) coupled to a diode array detector (DAD) and a SIL-10ADVP autosampler was used for chromatographic analysis of ergosterol from the treated Candida. The separation column used was an ODS $(250 \mathrm{~mm} \times 4.6 \mathrm{~mm}, 5 \mu \mathrm{m})$, and the mobile phase 


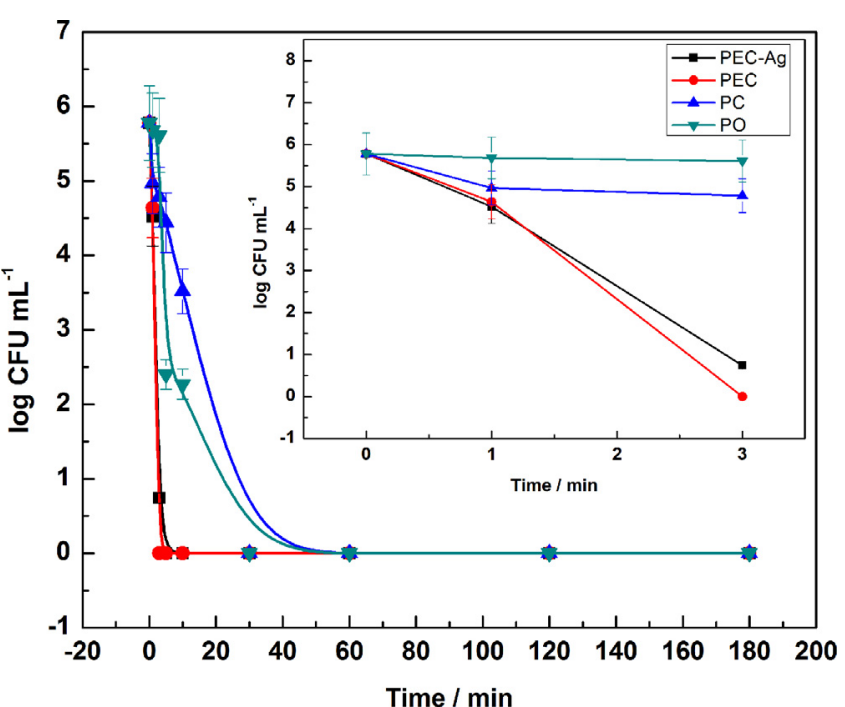

Fig. 1. Disinfection of $C$. parapsilosis sensu stricto $10^{6}$ cells $\mathrm{mL}^{-1}$ expressed in log scale obtained for $(-\ldots)$ photoelectrocatalytic ( $\mathrm{PEC}$ ) treatment using $\mathrm{Ti} / \mathrm{TiO}_{2}+\mathrm{UV}$ irradiation +1.5 V; $(-\mathbf{m})$ PEC-Ag treatment using $\mathrm{Ti} / \mathrm{TiO}_{2}-\mathrm{Ag}+\mathrm{UV}$ irradiation $+1.5 \mathrm{~V}$; ( - ) photocatalytic (PC) treatment using UV light with $\mathrm{Ti}^{-} \mathrm{TiO}_{2}$; and ( - ) photolytic (PO) treatment using only UV light. Values represent the mean \pm SD of independent assays. The variability among the methodologies was analyzed by ANOVA followed by Bonferroni post-test. PEC was the significantly most efficient methodology $(P<0.0001)$

$100 \%$ methanol, flow rate of $1 \mathrm{~mL} \mathrm{~min}^{-1}$, the elution was monitored at $\lambda=282 \mathrm{~nm}$. The extraction of ergosterol was carried out based on the method described by Yuan et al. [32] with few modifications. In the yeast samples obtained after the disinfection treatment ( $5 \mathrm{~mL}$ ), $3 \mathrm{~mL}$ of $25 \% \mathrm{KOH}$ (v/v, solution 3:2 methanol/ethanol) was added, and the homogenization was performed by vortexing for $1 \mathrm{~min}$. The mixture was heated at $85^{\circ} \mathrm{C}$ in a water bath for $1 \mathrm{~h}$. The ergosterol extraction was performed adding $3.0 \mathrm{~mL}$ of hexane followed by vigorous vortexing for $3 \mathrm{~min}$. Upper phase containing the hexane was transferred to a new glass tube and evaporated at room temperature. Subsequently, the sample was resuspended in $750 \mu \mathrm{L}$ of methanol filtered polytetrafluoroetielene membrane (PTFE) $0.45 \mu \mathrm{m}$ and injected in the chromatography. The experiments were performed in triplicate.

\subsection{Statistical analysis}

All statistical analyses were performed using Graph Pad Prism 5.0 for Windows (GraphPad Software, San Diego, CA, USA). The significance of difference $(P<0.05)$ was assessed using the two-way analysis of variance (ANOVA). A Bonferroni-test was carried out for post-hoc multiple comparisons.

\section{Results and discussion}

\subsection{Disinfection of Candida parapsilosis sensu stricto in planktonic forms}

Fig. 1 shows the inactivation of the microorganism expressed in log scale when treated using different methodologies. All proposed techniques killed the yeasts. Comparatively, the PEC methodology was significantly $(P<0.0001)$ more efficient. During the first $3 \mathrm{~min}$, the cultivable cells number decreased by $10^{6} \mathrm{CFU} \mathrm{mL}^{-1}$. The PEC process minimizes recombination of photogenerated charges, because under bias potential, the electrons are removed from the conduction band to an external counter electrode. This effect increases the availability of $\bullet \mathrm{OH}$ radicals on the electrode surface and other reactive oxygen species (ROS) that are able to attack the yeast in contact with the catalyst $[11,33]$. The results obtained are similar to those described in Mycobacterium disinfection [10,34], but it is important to highlight that this is the first time that photoelectrocatalysis is reported for Candida disinfection. In addition, the special tubular morphology of the nanotubes on $\mathrm{TiO}_{2}$ electrodes facilitates the transport of electrons resulting in increased rate of formation of $\bullet \mathrm{OH}$ radicals and ROS or direct load transfer to the yeast $[11,35]$.

The influence of silver $(\mathrm{Ag})$ on the performance of PEC was also evaluated. The results are shown in Fig. 1. The Ag incorporation did not improve the method as expected, but the slight increase could be attributed to the minimization of the recombination center for the $\mathrm{e}^{-} / \mathrm{h}^{+}$pairs photogenerated during photocatalyst irradiation [36].

The Ag mechanism in photoelectrocatalysis remains controversial [37], although it is well-known that silver ions and silver-based compounds are highly toxic to microorganisms. The dissolution of silver nanoparticles from the catalyst surface could release antimicrobial silver ions $\left(\mathrm{Ag}^{+}\right)$[38], which can interact with the thiol group of the protein, resulting in an inactivation of enzymes and leading to respiratory production of reactive oxygen species [39]. The $\mathrm{Ag}^{+}$ also prevents DNA replication and affects the structure and permeability of the cell membrane [40]. In another proposed mechanism, the silver can facilitate the adhesion of bacteria on the surface of the catalyst, resulting in an increase in photoactivity, because the nanoparticles can penetrate the bacterial cell and then more easily increase the permeability in the bacterial cell membrane [41]. However, in this study, the Ag incorporation did not improved the method as expected; these results indicate that in this case, the silver ion presence in the nanomaterial may act as a recombination center for the $\mathrm{e}^{-} / \mathrm{h}^{+}$pairs.

Conversely, the photocatalytic (PC) treatment achieved a decrease of $10^{6} \mathrm{CFU} \mathrm{mL}{ }^{-1}$ after only 30 min treatment (Fig. 1). It was reported that in the presence of air or oxygen, the irradiated semiconductor nanoparticles compromise cellular integrity, mainly by damaging the cellular envelopes and plasma membrane [31]. The mechanism that leads to cell death has been proposed by many studies. Several authors suggest a drastic oxidative stress, generated by direct contact of activated $\mathrm{TiO}_{2}$ on the cell surface $[42,43]$. Thabet et al. [44] suggested that the $\mathrm{TiO}_{2}$ nanoparticles target the plasma membrane by infiltration of the fungal wall due to the progression of localized damaged areas. These membrane perforations gradually released cations and anions from yeast cells, and intracellular proteins were progressively targeted, which could constitute a main antimicrobial element [44].

The photolytic treatment ( $\mathrm{PO}$ ) provided the slowest disinfection: 60 min of treatment was necessary to achieve a decrease of $10^{6} \mathrm{CFU} \mathrm{mL}^{-1}$ (Fig. 1). It is reported that UV-A can promote oxidation reactions that mainly damage DNA molecules (mostly base modifications and DNA strand breaks) [45]. Considering that nucleobases weakly absorb wavelengths higher than $320 \mathrm{~nm}$, most of the damaging effect of UV-A on cellular DNA involves photosensitization reactions leading to photo oxidations within cells [46]. Although this damage can be repaired by the cell after a certain time, if the cell stress is excessive, it may die or become incapable of further division [42,47-49]. In addition, previous studies have shown that the efficiency of the electrochemical oxidation process using both $\mathrm{Ti} / \mathrm{TiO}_{2}$ nanotubes and applied potential show negligent inactivation [46].

The results obtained in this work were better than those reported in the literature [50-52] using photocatalysis (without bias potential) or photolytic irradiation. Kühn et al. [50] reported that the photocatalytic disinfection of Escherichia coli, Pseudomonas aeruginosa, Staphylococcus aureus and Enterococcusfaecium reduced more than $6 \log _{10}$ steps in the 60 min treatment. Using Candida albicans, the efficiency was only $2 \log$. Mitoraj et al. [51] reported that 
carbon-doped titanium dioxide and $\mathrm{TiO}_{2}$ modified with platinum (IV) chloride complexes used as catalyst in suspension or immobilized at the surface of plastic can be used to treat $C$. albicans, but the results indicate a highly resistant behavior. The reduction of $C$. albicans reached $70 \%$ to $75 \%$ in the carbon-doped $\mathrm{TiO}_{2}$ suspension system $\left(10^{6} \mathrm{CFU} \mathrm{mL} \mathrm{m}^{-1}, 1 \mathrm{~g} \mathrm{~L}^{-1}\right)$ under UV-visible irradiation after $60 \mathrm{~min}$. In addition, the use of $\mathrm{TiO}_{2}$ and $\mathrm{Ag}-\mathrm{TiO}_{2}$ were evaluated in the photocatalytic disinfection of $C$. albicans using near the visible irradiation region. The method reached only $80 \%$ of $C$. albicans reduction after $60 \mathrm{~min}$ of treatment [52].

Fungi belong to a kingdom of eukaryotic organisms and thus possesses a membrane-bound nucleus protecting their DNA and a compartmented subcellular organization constituted by organelles. The fungi's envelope is constituted, from the inside out, by a plasma membrane (lipid bilayer interspersed with globular proteins) and differs from bacteria by a thick prominent cell wall comprising $15-25 \%$ of the dry mass of the cell. The main structural constituents of yeast walls are polysaccharides (80-90\%), but other components include mannoproteins, lipids and inorganic phosphate [53]. Yeast cytoplasm delimited by the plasma membrane is an aqueous acidic colloidal fluid containing soluble macromolecules such as proteins or sugars. Thus, the complexity and density of the cell wall increase from bacteria to fungus. Kühn et al. [50] coated Plexiglas with Degussa P25 $\mathrm{TiO}_{2}$ and investigated its microbial effects toward the destruction of E. coli, P. aeruginosa, $S$. aureus, E. faecium and C. albicans. In the case of bacteria, a reduction efficiency (RE) more than $6 \log _{10}$ steps in 60 min was observed; using C. albicans, only an RE of $2 \log _{10}$ steps in 60 min was observed. The results show that REs were found to decrease in the following order: E. coli $>$ P. aeruginosa $>$ S. aureus $>$ E. faecium $>C$. albicans. The complexity and density of the cell wall increased in the same order of precedence: E. coli and $P$. aeruginosa have thin and slack cell walls (Gram-negative), S. aureus and E. faecium have thicker and denser cell walls (Gram-positive), and C. albicans has a thick eukaryotic cell wall. In previous works we had been studied the efficiency of the photoelectrocatalysis treatment applied to Mycobacteria. This treatment allowed total disinfection within 3 min. [10,34,37]. These results show that the method is very promising for disinfection of all microorganisms.

Considering that the PEC treatment promotes the mineralization of organic compounds leached after cell damage, studies were conducted to monitor the removal of total dissolved organic carbon during the treatment. These results are shown in Fig. 2. Except for PEC-Ag (time-point, $3 \mathrm{~min}$ ), PEC was shown to be a significantly $(P<0.001)$ better methodology. The mineralization of Candida can be divided into three different regions: (i) initial incubation period (before $3 \mathrm{~min}$ ) called the "shoulder", where the hydroxyl radicals could attack the yeasts; (ii) the second period ( $3 \mathrm{~min}<t<10 \mathrm{~min}$ ), where fast inactivation of the microorganism occurs; (iii) "tail" region where the process is being decelerated after 10 min $[54,55]$. There are several possible explanations for this deceleration, such as the screening effect of the yeast or a competition between the yeast and the organic by-products released to the solution by the inactivated yeast for the photogenerated hydroxyl radicals.

Furthermore, the ergosterol is one of the major components of the yeast cell membrane and is responsible for maintaining cell integrity and function [53]. Thus, the degradation of ergosterol was monitored by high-performance liquid chromatography coupled to a diode array. The chromatograms obtained in the start of the treatment and after 3 min of PEC treatment are shown in Fig. 3. At the start of the PEC treatment, it is possible to verify the ergosterol presence identified for a peak at retention time of $4.2 \mathrm{~min}$ (Fig. 3a, peak I). Nevertheless, after 3 min of treatment is seen the complete absence of ergosterol (Fig. 3b). This result indicates that PEC treatment also promoted full degradation of the ergosterol, which confirms the TOC removal observed previously.

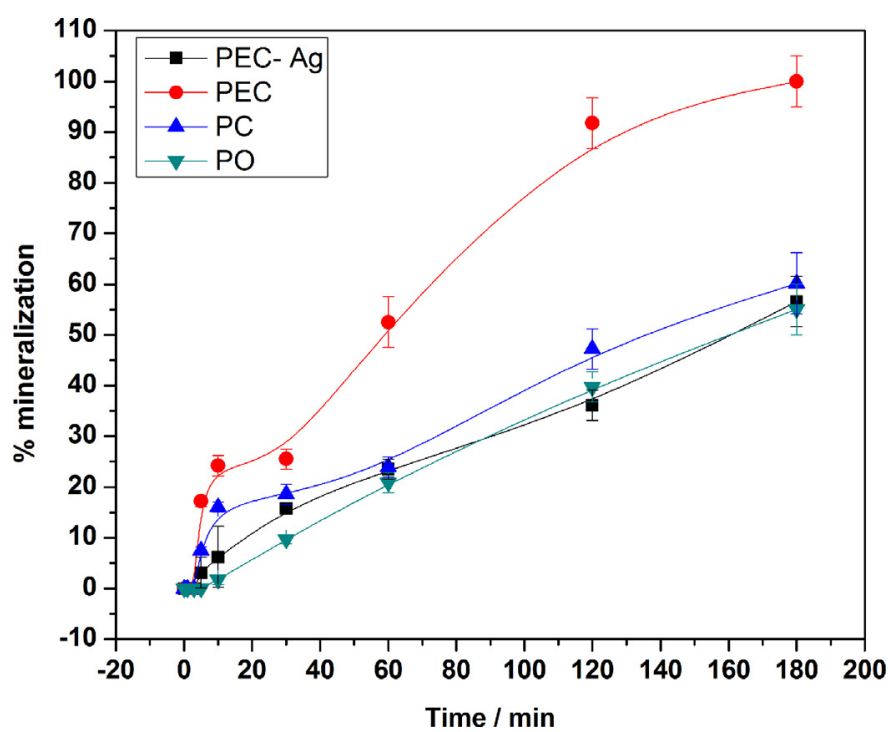

Fig. 2. Mineralization percentage obtained for $C$. parapsilosis sensu stricto $10^{6}$ cells $\mathrm{mL}^{-1}$ applying ( $\_$) photoelectrocatalytic (PEC) treatment using $\mathrm{Ti} / \mathrm{TiO}_{2}+\mathrm{UV}$ irradiation $+1.5 \mathrm{~V} ;(-)$ PEC-Ag treatment using $\mathrm{Ti} / \mathrm{TiO}_{2}-\mathrm{Ag}+\mathrm{UV}$ irradiation $+1.5 \mathrm{~V}$; ( - ) photocatalytic (PC) treatment using UV light with $\mathrm{Ti} / \mathrm{TiO}_{2}$; and ( $\longrightarrow$ ) photolytic (PO) treatment using only UV light. Values represent the mean \pm SD of independent assays. The variability among the methodologies was analyzed by ANOVA followed by Bonferroni post-test. PEC was the significantly most efficient methodology $(P<0.001)$.

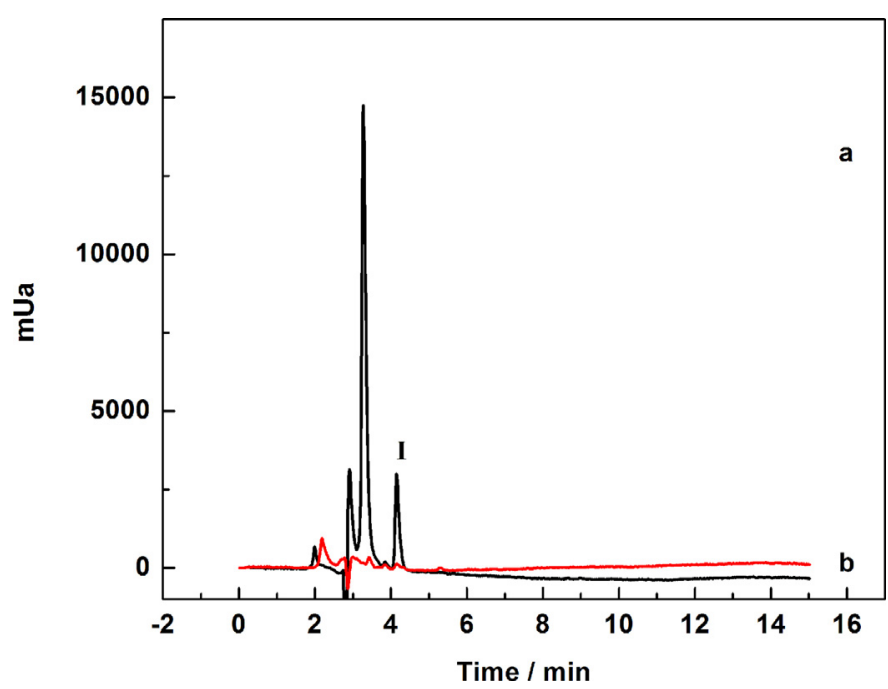

Fig. 3. Chromatograms obtained of ergosterol analysis (a) at the start and (b) after 3 min of PEC treatment. Chromatographic conditions: mobile phase: $100 \%$ methanol, flow rate $=1 \mathrm{~mL} \mathrm{~min}^{-1}, \lambda=282 \mathrm{~nm}$.

Considering the good results obtained with the treatment of planktonic cells, the photoeletrocatalytic treatment was further applied to yeasts in the biofilm growth mode.

\subsection{Disinfection of water containing Candida parapsilosis sensu stricto biofilm form}

Both bacteria and yeast can attach to surfaces to form biofilms [56,57]. Biofilm formation by each Candida species varies depending on the material [58]. The biofilms ( $48 \mathrm{~h}$ ) of $C$. parapsilosis sensu stricto were performed on PVC, silicone and PTFE, and these biofilms were submitted to the same treatments applied to planktonic cells. In this study, C. parapsilosis sensu stricto showed great biofilm formation capacity on all three materials studied, although 

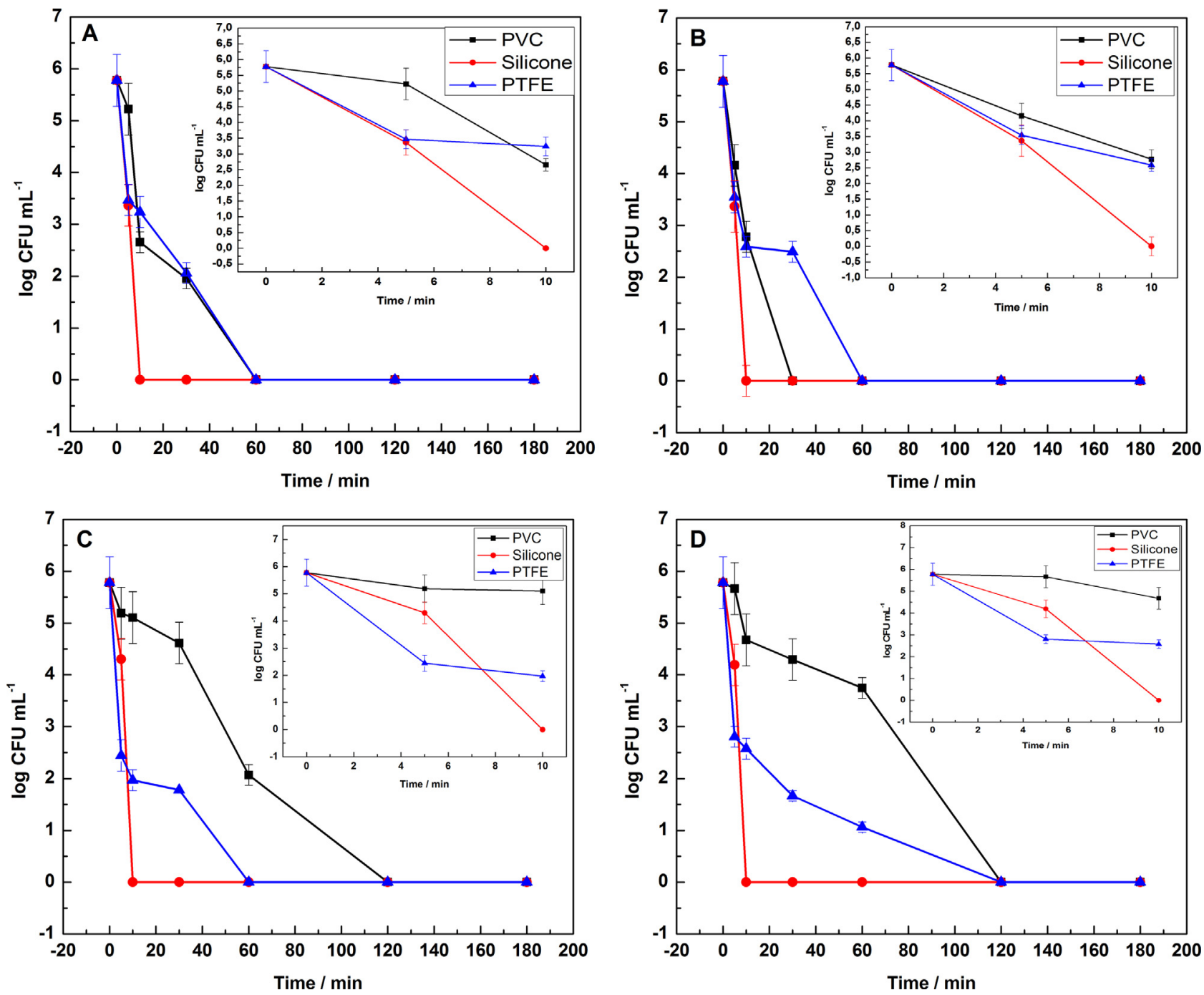

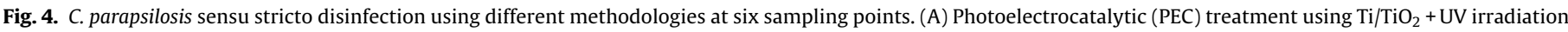

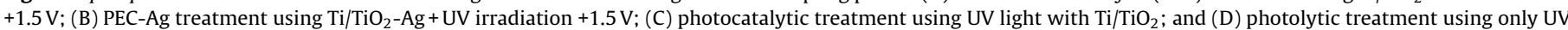

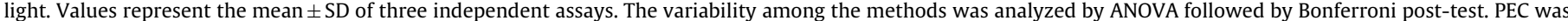
the significantly most efficient methodology $(P<0.001)$.

biofilms on PVC were more homogeneous and consistent (data not shown) in agreement with Estivill et al. [59]. The results of disinfection obtained for $C$. parapsilosis sensu stricto biofilms are shown in Fig. 4A-D. After 60, 10 and 60 min of treatment (Fig. 4A) PEC methodology decreased by $10^{6} \mathrm{CFU} \mathrm{mL}^{-1}$ on fungal biofilms whereas PEC-Ag methodology provided the same effect after 30 , 10 and $60 \mathrm{~min}$ (Fig. 4B) for biofilms performed on PVC, silicone and PTFE, respectively. For both photocatalytic (Fig. 4C) and photolysis (Fig. 4D) treatments, the results showed an antifungal effect after 120,10, and 60 min using biofilms performed on PVC, silicone and PTFE, respectively. PVC is the material that showed the most resistance in all tested disinfection treatments. In agreement with previous studies [60,61], microbial attachment to PVC was stronger than that on latex and silicone because of some properties of its surface such as texture, charge and hydrophobicity [60,61].

Comparatively, the results showed that the PEC methodology was more efficient $(P<0.001)$ in the inactivation of planktonic cells that the biofilms. The high content of polysaccharide constituents of the biofilm matrix, formation of hydrogen bonds on the surface of the nanoparticles and other process increase the difficulty of the oxidation process. Such linkages reduce the tendency of $\mathrm{TiO}_{2}$ nanoparticles to accept protons [62].
Further studies were conducted to monitor the fungal biofilm degradation on PVC, silicone and PTFE by total organic carbon removal (mineralization) assays. The results indicated high variability after $180 \mathrm{~min}$ of treatment (Fig. 5A-D) for all materials. The results obtained with PEC methodology were 71, 91 and 92\% mineralization (Fig. 5A); with PEC-Ag methodology, the results were 79, 83 and $92 \%$ mineralization (Fig. 5B); with PC methodology, the results were 70,70 and $79 \%$ mineralization (Fig. 5C); and with PO methodology, the results were 59,61 and $62 \%$ mineralization after 180 min of treatment (Fig. 5D) with biofilms performed on PVC, silicone and PTFE, respectively. The results obtained showed that PEC is a promising process for the inactivation of $C$. parapsilosis sensu stricto in planktonic growth or biofilms.

\section{Conclusions}

Our findings indicated that the photoelectrocatalytic oxidation conducted at $\mathrm{Ti} / \mathrm{TiO}_{2}$ and $\mathrm{Ti} / \mathrm{TiO}_{2}-\mathrm{Ag}$ nanotube photoanodes is a powerful strategy to inactivate $C$. parapsilosis sensu stricto. It was possible to obtain total inactivation for aqueous solutions infected with the yeast after only 3 min of treatment for planktonic cells. Monitoring of the degradation of the metabolites showed 

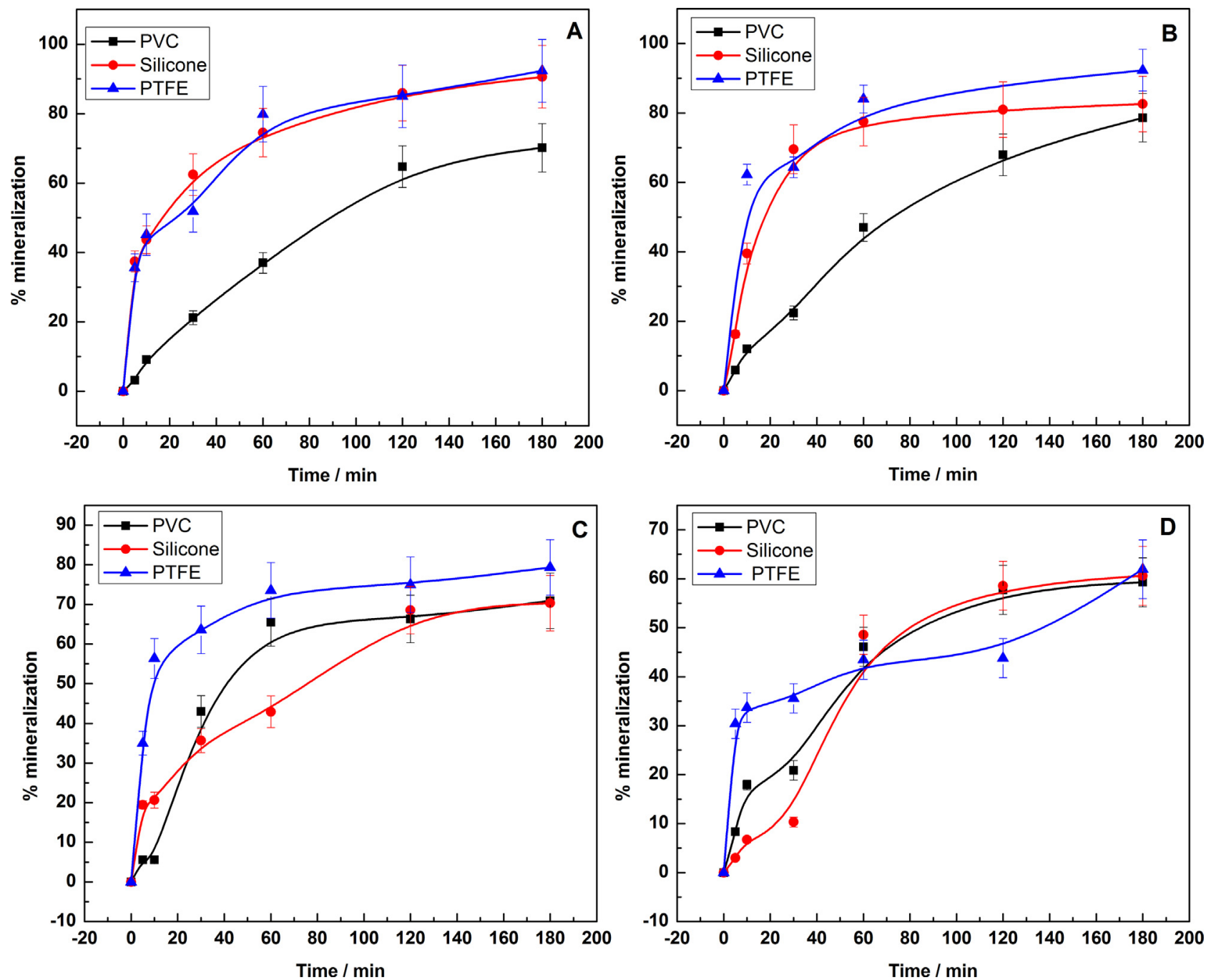

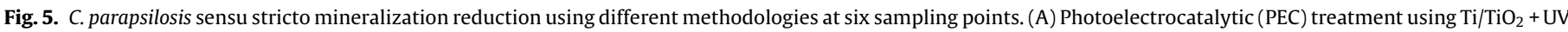

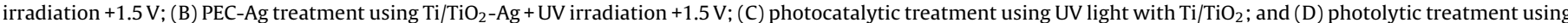

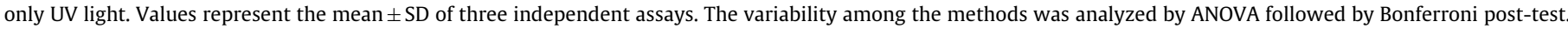
PEC was the significantly most efficient methodology $(P<0.001)$.

ergosterol degradation after $3 \mathrm{~min}$ of photoelectrocatalytic treatment, as shown by HPLC-DAD, and $91 \%$ degradation of organic matter according to the results obtained with a total organic carbon analyser. Variability in treatment time with different techniques tested was observed for the disinfection of fungal biofilms grown on PVC, silicone and PTFE. The C. parapsilosis sensu stricto biofilms on PVC showed more resistant behavior; however, after $120 \mathrm{~min}$ of treatment, the total organic carbon removal reached $54-98 \%$ for all biofilms. Therefore, these results show that the photoelectrocatalytic treatment could be a promising alternative to inactivate the yeast, including that on biofilm forms.

\section{Acknowledgment}

This work at the Faculdade de Ciências Farmacêuticas de Araraquara, FCFAr-UNESP was supported by grants from the Fundação de Amparo à Pesquisa do Estado de São Paulo (FAPESP), fellowship \# 2011/12734-3 and \# 2009/09403-5, and project \# 2012/01270-9.

\section{References}

[1] M.F. Kabir, F. Haque, E. Vaisman, C.H. Langford, A. Kantzas, Int. J. Chem. React. Eng. 1 (2003) 1542.
[2] J. Xu, Y. Ao, D. Fu, J. Iin, Y. Lin, X. Shen, C. Yuan, Z. Yin, J. Photochem. Photobiol. A: Chem. 199 (2008) 165.

[3] L. Körösi, S. Papp, I. Bertóti, I. Dékány, Chem. Mater. 19 (2007) 4811.

[4] D. Chu, X. Yuan, G. Qin, M. Xu, P. Zheng, J. Lu, L. Zha, J. Nanopart. Res. 10 (2008) 357.

[5] K.K. Akurati, A. Vital, G. Fortunato, R. Hany, F. Nueesch, T. Graule, Solid State Sci. 9 (2007) 247.

[6] J.M. Macak, M. Zlamal, J. Krysa, P. Schmuki, Small 3 (2007) 300.

[7] M.R. Hoffmann, S.T. Martin, W. Choi, D.W. Bahnemann, Chem. Rev. 95 (1995) 69.

[8] F.M.M. Paschoal, M.A. Anderson, M.V.B. Zanoni, J. Hazard. Mater. 166 (2009) 531.

[9] J.C. Cardoso, T.M. Lizier, M.V.B. Zanoni, Appl. Catal. B: Environ. 99 (2010) 96.

[10] M.F. Brugnera, M. Miyata, G.J. Zocolo, C.Q.F. Leite, M.V.B. Zanoni, Electrochim. Acta 85 (2012) 33.

[11] M. Cho, H. Chung, W. Choi, J. Yoon, Water Res. 38 (2004) 1069.

[12] M. Cho, H. Chung, W. Choi, J. Yoon, Appl. Environ. Microbiol. 71 (2005) 270.

[13] A.G. Rincon, C. Pulgarin, N. Adler, P. Péringer, J. Photochem. Photobiol. A: Chem. 139 (2001) 233.

[14] G.M. Walker, Yeast Physiology and Biotecnology, John Wiley \& Sons, Chichester, UK, 1998, pp. 12-33.

[15] H.C. Flemming, T.R. Neu, D.J. Wozniak, J. Bacteriol. 189 (2007) 7945

[16] H.C. Flemming, J. Wingender, Nat. Rev. Microbiol. 8 (2010) 623.

[17] S.R. Lockhart, S.A. Messer, M.A. Pfaller, D.J. Diekema, J. Clin. Microbiol. 46 (2008) 2659

[18] M.A. Pfaller, R.N. Jones, G.V. Doern, H.S. Sader, R.J. Hollis, S.A. Messer, J. Clin. Microbiol. 36 (1998) 1886.

[19] D. Trofa, A. Gacser, J.D. Nosanchuk, Clin. Microbiol. Rev. 21 (2008) 606

[20] S.A. Messer, R.N. Jones, T.R. Fritsche, J. Clin. Microbiol. 44 (2006) 1782. 
[21] A. Tavanti, A.D. Davidson, N.A. Gow, M.C. Maiden, F.C. Odds, J. Clin. Microbiol 43 (2005) 284.

[22] R.H. Pires, J.M. dos Santos, J.E. Zaia, C.H. Gomes Martins, M.J. Soares Mendes-Giannini, Mem. Inst. Oswaldo Cruz 106 (2011) 646.

[23] R.H. Pires-Gonçalves, F.G. Sartori, L.B. Montanari, J.E. Zaia, M.S.C. Melhem, M.J.S. Mendes-Giannini, C.H.G. Martins, Lett. Appl. Microbiol. 46 (2008) 542.

[24] S.D. Varo, C.H. Martins, M.J. Cardoso, F.G. Sartori, L.B. Montanari, R.H. Pires-Gonçalves, Rev. Soc. Bras. Med. Trop. 40 (2007) 326.

[25] A.V. Jung, P.L. Cann, B. Roig, O. Thomas, E. Baures, M.F. Thomas, Int. J. Environ. Res. Public Health 11 (2014) 4292.

[26] M.F. Brugnera, K. Rajeshwar, J.C. Cardoso, M.V. Zanoni, Chemosphere 78 (2010) 569.

[27] E. Leoni, P.P. Legnani, J. Appl. Microbiol. 90 (2001) 27.

[28] R.H. Pires, J.F. da Silva, C.H. Gomes Martins, A.M. Fusco Almeida, C.P. Soares, M.J. Soares Mendes-Giannini, Antimicrob. Agents Chemother. 57 (2013) 2417

[29] G. Ramage, K. Vande Walle, B.L. Wickes, J.L. Lopez-Ribot, Antimicrob. Agents Chemother. 45 (2001) 2475

[30] C.G. Pierce, P. Uppuluri, A.R. Tristan, F.I. Wormley Jr., E. Mowat, G. Ramage, J.L. Lopez-Ribot, Nat. Protoc. 3 (2008) 1494.

[31] P. Chuaybamroong, C. Thunyasirinon, S. Supothina, P. Sribenjalux, C.Y. Wu, Chemosphere 83 (2011) 730.

[32] J.P. Yuan, J.H. Wang, X. Liu, H.C. Kuang, X.N. Huang, J. Agric. Food Chem. 54 (2006) 6172.

[33] S. Malato, J. Blanco, D.C. Alarcón, M.I. Maldonado, P. Fernández-Ibáñez, W. Gernjak, Catal. Today 122 (2007) 137.

[34] M.F. Brugnera, M. Miyata, G.J. Zocolo, C.Q.F. Leite, M.V.B. Zanoni, Water Res. 47 (2013) 6596.

[35] P. Pichat, Molecules 19 (2014) 15075.

[36] M. Tyllianakis, E. Dalas, M. Christofidou, J.K. Kallitsis, A. Chrissanthopoulos, P.G. Koutsoukos, C. Bartzavali, N. Gourdoupi, K. Papadimitriou, E.K. Oikonomou, S.N. Yannopoulos, D. Sevastos, J. Mater. Sci.: Mater. Med. 21 (2010) 2201.

[37] M.F. Brugnhera, M. Miyata, C.Q.F. Leite, M.V.B. Zanoni, J. Photochem. Photobiol. A: Chem. 278 (2014) 1.

[38] J.R. Morones, J.L. Elechiguerra, A. Camacho, K. Holt, J.B. Kouri, J.T. Ramírez, M.]. Yacaman, Nanotechnology 16 (2005) 2346.

[39] Y. Matsumura, K. Yoshikata, S. Kunisaki, T. Tsuchido, Appl. Environ. Microbiol. 69 (2003) 4278
[40] Q L. Feng J. Wu, G.Q Chen, F Z Cui, T.N. Kim, J.O Kim, J. Biomed Mater. Res. A 52 (2000) 662

[41] I. Sondi, B. Salopek-Sondi, J. Colloid Interface Sci. 275 (2004) 177.

[42] G. Gogniat, S. Dukan, Appl. Environ. Microbiol. 73 (2007) 7740.

[43] C. Guillard, T.-H. Bui, C. Felix, V. Moules, B. Lina, P. Lejeune, Comptes Rendus Chim. 11 (2008) 107

[44] S. Thabet, M. Weiss-Gayet, F. Dappozze, P. Cotton, C. Guillard, Appl. Catal. B: Environ. 140-141 (2013) 169

[45] S. Kozmin, G. Slezak, A. Reynaud-Angelin, C. Elie, Y. de Rycke, S. Boiteux, E. Sage, Proc. Natl. Acad. Sci. U. S. A. 102 (2005) 13538.

[46] J. Cadet, E. Sage, T. Douki, Mutat. Res. 571 (2005) 3.

[47] B. Cao, Y. Wang, N. Li, B. Liu, Y. Zhang, Dent. Mater. J. 32 (2013) 311.

[48] H.A. Foster, I.B. Ditta, S. Varghese, A. Steele, Appl. Microbiol. Biotechnol. 90 (2011) 1847.

[49] J. Lonnen, S. Kilvington, S.C. Kehoe, F. Al-Touati, K.G. McGuigan, Water Res. 39 (2005) 877.

[50] P. Kühn, I.F. Chaberny, K. Massholder, M. Stickler, V.W. Benz, H.G. Sonntag, L. Erdinger, Chemosphere 53 (2003) 71.

[51] D. Mitoraj, A. Janczyk, M. Strus, H. Kisch, G. Stochel, P.B. Heczko, W. Macyk, Photochem. Photobiol. Sci. 6 (2007) 642.

[52] I. Tatlıdil, M. Sökmen, C. Breen, F. Clegg, C.K. Buruk, E. Bacaksız, J. Sol-Gel Sci. Technol. 60 (2011) 23.

[53] S.J. Free, Adv. Genet. 81 (2013) 33.

[54] A.K. Benabbou, Z. Derriche, C. Felix, P. Lejeune, C. Guillard, Appl. Catal. B: Environ. 76 (2007) 257.

[55] N. Baram, D. Starosvetsky, J. Starosvetsky, M. Epshtein, R. Armon, Y. Ein-Eli, Electrochim. Acta 54 (2009) 3381

[56] G. Ramage, C. Williams, Adv. Appl. Microbiol. 84 (2013) 27.

[57] R.M. Donlan, J.W. Costerton, Clin. Microbiol. Rev. 15 (2002) 167

[58] M. Tumbarello, B. Posteraro, E.M. Trecarichi, B. Fiori, M. Rossi, R. Porta, K. de Gaetano Donati, M. La Sorda, T. Spanu, G. Fadda, R. Cauda, M. Sanguinetti, J. Clin. Microbiol. 45 (2007) 1843.

[59] D. Estivill, A. Arias, A. Torres-Lana, A.J. Carrillo-Munoz, M.P. Arevalo, J. Microbiol. Methods 86 (2011) 238.

[60] R.O. Darouiche, Clin. Infect. Dis. 33 (2001) 1567.

[61] A. Pascual, Clin. Microbiol. Infect. 8 (2002) 256.

[62] M.B. Romanello, M.M. Fidalgo de Cortalezzi, Water Res. 47 (2013) 3887. 